\title{
Properties, Production and Applications of NiTi Shape Memory Alloy
}

Eva Kristianová, Pavel Novák

University of Chemistry and Technology, Prague, Department of Metals and Corrosion Engineering, Technická 5, 166

28 Prague 6, Czech Republic, E-mail: ekris.5@seznam.cz, panovak@vscht.cz

Approximately equiatomic alloy Ni-Ti is commercially most successful member of shape memory material group. This paper concludes basic knowledge about properties, ways of preparation and possible applications of this unique material in medicine, industry, construction or everyday life.

Keywords: NiTi, shape memory, properties, production

\section{Acknowledgement}

This research was financially supported by the Czech Science Foundation, project No. 14-03044S.

\section{References}

[1] KAUFFMAN, G.B., MAYO, I. (1997). The story of nitinol: the serendipitous discovery of the memory metal and its applications. In: The chemical educator, Vol. 2, No. 2, pp. 1-21. Springer. Germany

[2] WILKES, K., LIAW, P.,WILKES, K. (2000). The fatigue behavior of shape-memory alloys. In: JOM, Vol. 52, No. 10, pp. 45-51. Springer. Germany.

[3] MIHÁLCZ, I. (2001). Fundamental characteristics and design method for nickel-titanium shape memory alloy. In: Mechanical Engineering, Vol. 45, No. 1, pp. 75-86. BME. Hungary.

[4] MILOŠEV, I., KAPUN, B. (2012). The corrosion resistance of Nitinol alloy in simulated physiological solutions: Part 1: The effect of surface preparation. In: Materials Science and Engineering: C, Vol. 32, No. 5, pp. 10871096. Elsevier. Netherlands.

[5] VOJTĚCH, D., KUBÁSEK, J., NOVÁK, P. (2013). Corrosion properties of the superelastic shape memory Ni-Ti alloy for medical implants. In: Manufacturing Technology, Vol. 13, No. 3, pp. 409-414. UJEP. Czech Republic

[6] NOVÁK, P., MEJZLÍKOVÁ, L., MICHALCOVÁ, A., ČAPEK, J. BERAN, P., VOJTĚCH, D. (2013). Effect of SHS conditions on microstructure of NiTi shape memory alloy. In: Intermetallics, Vol. 42, pp. 85-91. Elsevier. Netherlands.

[7] NAKAHATA, T. (2011). Industrial processing of titanium-nickel (Ti-Ni) shape memory alloys (SMAs) to achieve key properties, In: Shape Memory and Superelastic Alloys, pp. 53-62. Woodhead Publishing. United Kingdom.

[8] NOVÁK, P., KŘÍŽ, J., MICHALCOVÁ, A., SALVETR, P. (2015). Role of reactive sintering in production of technically important intermetallics. In: Manufacturing Technology, Vol. 15, No. 1, pp. 74-77. UJEP. Czech Republic

[9] OZAWA, M., SUZUKI, A., INABA, T. (2011). The use of shape memory alloys (SMAs) in construction and housing. In: Shape Memory and Superelastic Alloys, pp. 110-119. Woodhead Publishing. United Kingdom.

[10] MORGAN, N.B. (2004). Medical shape memory alloy applications - the market and its products. In: Materials Science and Engineering: A, Vol. 378, No. 1-2, pp. 16-23. Elsevier. Netherlands

[11]HABU, T. (2011). Applications of superelastic alloys in the clothing, sports and leisure industries. In: Shape Memory and Superelastic Alloys, pp. 169-175. Woodhead Publishing. United Kingdom 